\author{
Marquette University \\ e-Publications@Marquette
}

3-2015

\title{
Two French Variations on Truth: Ricoeur's Attestation and Foucault's "Parrhesiastic" Attitude
}

Pol Vandevelde

Marquette University, pol.vandevelde@marquette.edu

Follow this and additional works at: https://epublications.marquette.edu/phil_fac

Part of the Philosophy Commons

\section{Recommended Citation}

Vandevelde, Pol, "Two French Variations on Truth: Ricoeur's Attestation and Foucault's "Parrhesiastic" Attitude" (2015). Philosophy Faculty Research and Publications. 506.

https://epublications.marquette.edu/phil_fac/506 


\section{Marquette University}

\section{e-Publications@Marquette}

\section{Philosophy Faculty Research and Publications/College of Arts and Sciences}

This paper is NOT THE PUBLISHED VERSION; but the author's final, peer-reviewed manuscript. The published version may be accessed by following the link in the citation below.

Journal of the British Society for Phenomenology, Vol. 46, No. 1 (2015): 33-47. DOI. This article is (C) Taylor \& Francis and permission has been granted for this version to appear in $\underline{\text { e- }}$ Publications@Marquette. Taylor \& Francis does not grant permission for this article to be further copied/distributed or hosted elsewhere without the express permission from Taylor \& Francis.

\section{Two French Variations on Truth: Ricoeur's Attestation and Foucault's "Parrhesiastic" Attitude}

Pol Vandevelde

Department of Philosophy, Marquette University, Milwaukee, WI

\section{Abstract}

Both Ricoeur and Foucault, apparently independently of each other, dedicated much effort to provide an account of truth that goes far beyond the truth of sentences, propositions, or judgments. While well aware of the speech act theory and pragmatics, they want to go beyond a formalism of rules of speech or arguments and integrate the attitude of the one who speaks in the very notion of truth. They see truth not merely as a property of statements, but as an existential process in such a way that the truth of statements is linked to the historically situated speaker. Truth as a property of statements is related to truth as an event. However, both reject any form of historicism or relativism.

I examine Ricoeur's notion of attestation and Foucault's notion of parrhesia, showing how both notions represent a kind of "poetics of truth", which combines the existential position of the speaker and the historical circumstances of utterance. I show the extent to which both poetics of truth are political and ethical and how 
successful each poetics is: Ricoeur believes that he can maintain a claim to universality whereas Foucault abandons such a claim and instead subscribes to a radical singularity of the event of speech in a mode of truth that is, as he says, "polemic".

There is some irony in treating Ricoeur and Foucault together as operating in a common enterprise. The irony is not so much due to the fact that they were at one time in competition for replacing Jean Hyppolite at the Collège de France, Foucault obtaining the position and Ricoeur going to the University of Louvain, where he taught for several years. Rather, the irony is that Ricoeur represents hermeneutics - in all its forms, endeavours, and achievements - whereas Foucault from the start rejected it - in both its method and ambition - claiming that his "archaeology" offered a more rigorous and fruitful method. However, in his last lectures at the Collège de France, Foucault seems to have a change of heart and uses the expression of "hermeneutics of the subject" to name explicitly one of his lecture courses of 1982-83 and implicitly his own enterprise of re-examining the question of the subject in ancient Greek and Roman thought during the Hellenistic period and early Christianity.

In what follows, I do not intend to pursue historical considerations about influences between them or claim that Ricoeur explicitly reformulated Foucault's views. Rather, I intend to show why both Ricoeur and Foucault believe that the truth of what is said cannot be confined to the meaning content or the propositional content or the judgments expressed in what is said. Their common goal is to broaden the concept of truth so as to include the attitude of the one who speaks ${ }^{1}$ and thus treat the truth as a historically situated phenomenon or an event. Fully aware of the speech act theory and pragmatics, both attempt to offer an alternative understanding of performance, one that is existential and historical. They belong in this respect to the trend of contemporary French philosophers who, under the influence of Heidegger, have emphasized the notion of "event" (Marion, Romano, Badiou). Ricoeur and Foucault articulate the epistemological and ontological consequences of such a view of truth as event.

One of my motivations in comparing Ricoeur and Foucault on the side of their commonality is that neither of them equates historical situatedness with dependence on the historical situation or understands the relatedness of truth to circumstances of utterance as a form of relativization. Another of my motivations on the side of their difference is that, among those who emphasize the event, Ricoeur and Foucault are at the opposite end of the spectrum of possible positions. Ricoeur wants to maintain a claim to universality whereas Foucault abandons it in favour of a radical singularity of the event of speech.

Of their views I will only focus on two central notions: attestation (Ricoeur) and parrhesia (Foucault), which are rather similar in appearance. These two notions articulate a view of the truth as spoken or written and thus related to the historical circumstances of utterance and to the existential position of the speaker. For both Ricoeur and Foucault we can speak of a "poetics of truth" in the sense that the truth is, in some way to be specified, "produced". This poetics of truth takes the form of a configuration in Ricoeur and a drama in Foucault, who speaks of a "dramatic of discourse". I will show that, because it is a poetics of truth, thus arising out of concrete existential and historical circumstances, there are political and ethical components to it that coalesce in a different balance.

\section{Ricoeur: Speaking as Configuration}

In my discussion of Ricoeur I limit my topic to the specific act of speaking that is related to the past and about the past - the historical narratives - and focus exclusively on the status of the narrative itself, leaving out of consideration the issues of history and memory. A historical narrative is obviously about a past event, but, remarkably, it has to configure such an event so that it can be recounted. This poses an interesting problem of reference to the extent that the referent - the past event - is not available as such but only through accounts 
about it, such accounts having to be a reconstruction on the basis of documents, testimonies, and evidence of different sorts. The test that Ricoeur uses is a formulation by Leopold Ranke: to recount events "as they really [eigentlich] happened", which Ricoeur discusses in the third volume of Time and Narrative as well as in Memory, History, Forgetting. ${ }^{2}$ Unwittingly, Ranke expresses what Ricoeur calls the "enigma" ${ }^{3}$ of historical representation and implicitly acknowledges as insufficient two naïve options: first, a simple adequacy between what took place and the historical narrative about it and, second, a simple heterogeneity between them so that historical narratives would be mere "possible versions" of what took place. Against the first option, there is an obvious difference between the physics at the level of actions and events and the semantics at the level of words in narratives. Actions and events are not made of words or narratives and there is no direct route from narratives to events even if the former attempt to re-enact the past. Against the second option, there is an obvious sameness between the actions and events, on one side, and the narratives recounting them, on the other: historians and other chroniclers of the past claim that what is recounted in their respective narratives is "the same" as that which actually took place. Instead of a radical similarity or a radical heterogeneity between what took place and the historical narrative, Ranke's combination of the words "as" and "actually" offers a variation on what Ricoeur calls the three genres of "Difference", "Sameness", and "Analogy".

Because we have sameness - to recount what actually happened - we cannot simply say that a loss occurs when past events are recounted as if they had an internal meaning when occurring, which would be missed in part by the re-telling. Because we have difference - the recounting is not the event - we cannot simply say that a continuity exists between the events that took place and the retelling that followed them. The genre of analogy, thus, has the task of maintaining both sameness and difference without relying on loss or continuity. It is the analogy at work in the narrative itself - the "such as" in Ranke's expression - that is supposed to preserve the sameness of the physics of actions and events, but in another genre (speaking and writing) and another register (rendering the meaning of what took place). While the goal is to say what actually happened, the criterion of the truth cannot be in the events themselves, which cannot speak by themselves. They have to be established through documents and proofs, have to be understood and explained, and have to be presented in a narrative. These are the three phases of historical investigation: a documentary phase, an understanding/explanation phase, and a representing phase.

The third phase is the one that needs scrutiny. Ricoeur calls it représentance (representing, representation) or lieutenance (standing-in), where "representing [représentance] . . . means . . . the reduction to the same, the recognition of alterity, and the analogizing apprehension". ${ }^{4}$ Ricoeur understands this représentance as the translation of the German Vertretung (a notion he borrows from Karl Heussi) to name this fact that historical narratives render the past "such as it really happened". On the one hand, "things must have happened as they are told in the present narrative", ${ }^{5}$ but, on the other, "the 'really' is only signified by the 'such as'" ${ }^{6}$ Thus, we have the facts such "as" they "really" took place. The "representing" (représentance) consists in offering an equivalent of what took place, but by the same token, Ricoeur says, adduces an "increase of being" or an "increase of sense" or an "increase of meaning [surcroît d'être, surcroît de sens, augmentation de signification]". ${ }^{7}$

Ricoeur tries three models to secure the "such as it was" or the analogical transfer in order to fasten the analogy with the difference and the sameness. These three models are: mimesis (a narrative of action is a rendering of the narrative-like features of action), debt (the guarantee that the narrative is about the events that took place lies in the attitude of the one who recounts and who feels "in debt" towards the events of the past or the agents of past actions), and, lastly, attestation (the one who recounts the narrative attests to the truth of what is said by recounting it and to his character as truth-teller). I will focus here on the third one, attestation.

Ricoeur introduces the notion of attestation in its technical sense in Oneself as Another and even considers that it is the "password" (le "mot de passe") of the whole book. ${ }^{8}$ In an essay titled "L'attestation: entre 
phénoménologie et ontologie", ${ }^{9}$ he describes attestation as a "nondoxic" assurance in the sense that attestation is not manifested in the mode of a "believing that", but in the mode of "believing in": "The witness believes what he says and we believe in his sincerity". ${ }^{10}$ Attestation redoubles the truth of the statement and is, as such, a commitment that produces truth. Applied to the self,

attestation is the sort of confidence or assurance (nondoxic epistemological status) that each of us has of existing (ontological status) on the mode of self (phenomenological status). ${ }^{11}$

In Memory, History, Forgetting, Ricoeur expands the role of attestation beyond the issue of selfhood and applies it to narratives about the past. It is still about attesting oneself, but in relation to what one says when presenting an account of events, for example. Providing a narrative, as in the case of historians, is seen as an action that is imputed to the speaker or writer.

What I expect from my close relations is that they approve of what I attest: that I am able to speak, act, recount, impute to myself the responsibility for my actions. ${ }^{12}$

More specifically, when applied to historical narratives, attestation functions as what holds together the three phases of the historical reconstruction: the proof of the document, the analysis leading to intelligibility, and the writing of a narrative. The reason why we need attestation to hold the three components together is that the past is not powerful enough to impose itself on narratives and constrain them in such a narrow fashion that only "one" narrative or rendering would be correct. Ricoeur writes: "It is possible to compose several plots about the same incidents (which thus do not deserve any more to be called the same events)". ${ }^{13}$ The sentence in parentheses is the key. What then does an "event" consist of if several accounts can be given of it and if these different accounts can claim to be about "the same" event? What in an event can represent a resistance, or what Sartre calls the coefficient of adversity for the multiple narratives that can represent it? Put differently, if several different narratives can claim to be about the "same" event, for example President Jackson's actions at the origin of the Cherokees' "trail of tears", we have two options. In the first option, something in the event itself gives itself in possibly different manners and this explains why we have several and often differing accounts of President Jackson's actions. In the second option, "events" do not have a stable "essence". They can be carved out in different ways - out of the same mass of movements, gestures, and words - and reconfigured in opposite fashion; or they can even remain nonconfigured at all, thus offering no saliency, while still having some form of existence as possible "event" that can be carved out later. In this second option, according to which events do not have a stable essence, it is not so much that historians interpret differently the same event or rediscover the same event afterward, as if it had remained dormant in the meantime. Rather - and far more strongly - historians do not "discover" events, but "invent" them by determining in the mass of movements, gestures, and words specific discrete sequences that they present as facts. The documentary phase as well as the explanation and understanding phase differentiate their invention from a mere fabrication and distinguish history from fiction. However, as we will see, Ricoeur does not want to embrace this second option, but is not fully satisfied by the first one either.

Ricoeur borrows from Pierre Nora and Henri Irénée Marrou, but also from Heidegger, a distinction that he reformulates as one between event and fact. By event he means what actually happened and by fact he means what can be established through evidence, testimonies, and explanation. The difference is due to the status of the past. As Ricoeur writes,

the "having-been" causes a problem to the extent that it is not observable, whether it is the having-been of the event or the having-been of the testimony. The pastness [passéité] of an observation in the past is not itself observable, but memorable. ${ }^{14}$ 
We thus have a negative absence of things, people, and events - to the extent that they are "no more" - and a positive absence - to the extent that they have been and endure through the traces they have left.

Absence would thus be duplicated into the absence that is targeted by the present image and the absence of things past as far as they are gone, compared to their "having-been." 15

The first absence is of the past in its "being no more" (or of the "event") and the second is of the past that has left traces (or the "historical fact"). The latter is propositional: it is the fact "that" this and that happened.

The fact is not the event, itself given to the conscious life of a witness, but the contents of a statement meant to represent it. In this sense, we should always write: the fact that this occurred. ${ }^{16}$

By contrast, the event is what functions as the "ultimate referent" (référent ultime) ${ }^{17}$ of historical discourse or the counterpart, the vis-à-vis, ${ }^{18}$ which Ricoeur also expresses in German: the Gegenüber, another technical term he borrows from Heussi. By functioning in our historical narratives as the ultimate referent, the event in some sense preserves this past that is no more under the form of a past that "has been" or "has passed". As such, the event can also provide correctives to the narratives about the past.

It is to preserve this status of counterpart [vis-à-vis] of historical discourse that I distinguish the fact as "something said," the "what" of historical discourse, from the event as "that about which one talks" [la chose dont on parle], the "that about which the historical discourse speaks" [le "au sujet de quoi" est le discours historique.$^{19}$

This uncoupling of the event from the fact explains why the représentance or stand-in that is offered by historians - their historical narratives - is the mediation we have towards the event. The event does not give itself immediately, but has to be reconstructed and transformed into a fact: through proofs (the documentary phase), through intelligibility (the understanding/explanation phase), and through a narrative (the phase of representation). However, this uncoupling also leaves the event in a state of limbo, always at the horizon of the historical facts. Thus, it is in principle excluded that procedures and methods would be sufficient to secure or guarantee the analogical transfer of the physics of actions and events into the semantics of words and plots. Something else needs to intervene: the attitude of the author of the narrative. Such an attitude is not extraneous to the narrative, but is what "animates" it.

This attitude of the historian is implicitly acknowledged by both author and readers in the form of a tacit agreement or a "contract" (pacte) according to which readers should read the historical account "as if the things recounted did happen". ${ }^{20}$ It is analogous to the contract between authors of fiction and their readers, what Coleridge, quoted by Ricoeur, calls the "willful suspension of disbelief": readers of fiction are told, usually on the cover of the book, that what they are going to read is "not true" and they agree to read it in the mode of an "as if" - as if it were true. They suspend their disbelief. In the case of historical accounts, it is a suspension of suspicion: "The reader willingly suspends his disbelief, his incredulity, and he accepts playing along as if - as if the things recounted did happen". ${ }^{21}$ This also means that the contract raises expectations in readers and makes promises to them. ${ }^{22}$ This is where attestation becomes the fulcrum of the historical reconstruction. Historians are not mere story-tellers and entertainers. They lead us to believe that we will learn what "actually" happened and they promise some "revelations". To this extent, they commit themselves beyond their writing and engage their moral status. They attest to the truth of what is recounted and to their own character as truth-tellers. If challenged, technically, they can exhibit the documents used and present the explanatory procedures employed.

It is together that scripturality, comprehensive explanation, and documentary proof are capable of accrediting the truth claim of historical discourse. Only the movement that moves back from the art of 
writing to the "research techniques" and "critical procedures" is capable of raising the protest to the rank of what has become a critical attestation. ${ }^{23}$

Like the debt that Ricoeur mentions in Time and Narrative, where he presents historians as having a debt to the past, towards "what once was the case", ${ }^{24}$ attestation is an existential attitude. In Time and Narrative Ricoeur makes an analogy with painting and appeals to Cézanne who felt a debt

with respect to a vision which takes for him the significance of a logos which precedes him, which (pre)occupies him ... Added to this, the task of doing justice to the world has the value for us of being a hermeneutic key to the reading of phenomena. ${ }^{25}$

Like a painter the historian attempts "to 'render its due' to what is and to what once was [rendre son dû à ce qui est et ce qui fut]". ${ }^{26}$ Being-in-debt constitutes "the existential possibility of representing [représentance]". ${ }^{27}$ Ricoeur writes:

We tell stories because in the last analysis human lives need and merit being narrated. This remark takes on its full force when we refer to the necessity of saving the history of the defeated and the lost. The whole history of suffering cries out for vengeance and calls for narrative. ${ }^{28}$

However, attestation goes much farther than an existential attitude. For, being-in-debt as an existential attitude is blind towards its object. A previous decision has already been taken in favour of feeling in debt and thus the feeling itself, while attesting to the past, does not guarantee that justice is done to the past. To the contrary, being-in-debt involves an addressee of the debt - indebted to whose past? - as well as a modality - what kind of debt? As a consequence, the notion of debt may place too much emphasis on those who feel the debt and thus on those who tell the narrative. As we know, historians have had in the course of time rather different appreciations of what a debt involves. A debt is essentially what must be recognized. It is thus hard to impute a debt to somebody if that person rejects it. After all, it was in part as a debt to the victims of the battle of Kosovo in 1389, in which the Ottomans killed all males and raped all females (this is not "historically attested") ${ }^{29}$ that the Serb propaganda in the 1990s legitimated the "ethnic cleansing" of Muslims in Kosovo. To attempt "to save the history of the vanquished and the losers" ${ }^{\prime 30}$ may be too confined to the eye of the beholder and in need of further need for ethical grounding.

Ricoeur himself came to see the limits of the existential attitude.

It has to be acknowledged: the notions of counterpart [vis-à-vis], stand-in [lieutenance] constitute more the name of a problem than of the solution. In Time and Narrative III I confined myself to proposing a "conceptual articulation" for the enigma of adequacy by lieutenance. ${ }^{31}$

Because the past is neither fully formed before the representation we have of it nor fabricated by historians who would "represent" their favoured facts, we are left only with the attestation by the one who gives the narratives. It is the ethical component in a historical account that redoubles the truth of the narratives and makes them true. "We have nothing better than testimony and the critique of testimony in order to substantiate the historical representation of the past". ${ }^{32}$ Attestation is ethical in the sense that it is the performance by a real person in specific circumstances that binds the account given - the représentance or stand in - to the normative realm of human interactions. Attestation consists in saying: "Here I am!" thus presenting oneself as responsible for the correlation between what took place - the event - and the narrative that functions as the representation of the event. It is ethical because the author claims that it is about something that took place and is thus accurate (with the qualifications authors may want to use).

What is remarkable in attestation is that it is not a supplementary fact to the narrative given, but the making itself. Because the past that is gone cannot speak by itself but only to the extent that it matters and is relevant, 
because the events cannot force their own articulations other than by being established and documented facts, events are unstable referents: they can be "represented" in different ways given the different kinds of relevance they may have for different audiences. Thus, the representations of events by historians do not offer variations on commonly known events. Rather, it is their historiographical representation that is a making-true. As Ricoeur says, the historical account is an "attestation to reality" (attestation de réalité) ${ }^{33}$ and attestation is an "alethic mode" (mode aléthique (ou véritatif). As such, it is part of a poetics of truth in the sense that historical accounts are "made". They are produced not simply because they are written, but because past events manifest themselves as what "actually" happened under the responsibility of historians who attest to both the truth of the narrative and to their own being as truth-tellers. Because the event cannot present itself directly, but can only be represented, attestation is in the strong sense a making-true of what happened. "The phenomenology of testimony led the analysis of attestation to the threshold of doing history". ${ }^{34}$

However, because we have a correlation between events as ultimate referent and historical facts, Ricoeur can still maintain for historical narrative a claim to truth as universal or as correspondence: the claim to render the past such as it "really" was. It is not a reachable correspondence, only a claim that there is a referent beyond the representation and that such a referent can offer correctives to historical narratives. Although attestation as part of the production of the historical narrative is a poetics of truth, it is not a politics of truth. Facts matter, as we say. Even if they have to be established as facts and only count as such under the attestation performed by those who recount them, this "representation" is offered with a claim to refer to the event that has actually happened.

Let us now turn to Foucault who defends the same kind of view about the production of truth, but accepts that the poetics of truth is also a politics of truth.

\section{Foucault}

Regarding Foucault's views I will only focus on what he calls the "parrhesiastic attitude" or attitude of telling the truth, which he examines in his last lectures at the Collège de France from 1982 to his death in 1984 when studying the practice of the self in the Hellenistic period. ${ }^{35}$ The word is made of pan, which means "everything", and rheo, which means "to tell". Besides its pejorative meaning of telling everything and anything - the word means to tell everything - parrhesia means positively telling the truth when it matters. It came to be translated into Latin as oratio libera (free speech), licentia (licence), but generally as libertas, the etymon of "liberty". ${ }^{36}$ I will not examine the different forms the practice of telling the truth about oneself in the Hellenistic period took, but rather what Foucault calls the "parrhesiastic attitude", which he considers to be a possible attitude in philosophy today and which, we may surmise, he regards as his own philosophical attitude. ${ }^{37}$

When examining the practice of subjectivity in the Hellenistic period, Foucault is interested in the singularity of such a practice, but his focus on singularity is also part of what he calls the history of the present in the sense that his concern is not just historical or philological, but relates to our present situation. Through its difference with ours the ancient account of the self helps us understand ourselves better both in that which we lack and in the possibilities we may have. This investigation of singularities is a style of philosophizing that aims at conveying on any phenomenon under investigation its meaning, but one that is of a specific kind: it is a meaning that is, Foucault tells us, "variable, historical, and never universal". ${ }^{38} \mathrm{He}$ uses the expression of "parrhesiastic attitude" to qualify such an effort to find the singularity of an event or to focus on the unrepeatability of a phenomenon.

In Le courage de la vérité Foucault distinguishes the "parrhesiastic" philosophical attitude or the parrhesiastic philosophical discourse from other philosophical attitudes. ${ }^{39}$ These different attitudes concern the different ways the balance between truth, power, and morality manifests itself, which is, according to Foucault, at work in 
most phenomena. The first attitude is the prophetic one. It promises and predicts a perfect coincidence or reconciliation between the production of truth, the exercise of power, and the moral formation. The second attitude of wisdom aims at finding the commonality or unity of those three axes. The third "teaching" attitude consists in defining in their irreducible specificity the formal conditions of truth-telling (as in logic), the best conditions for exercising power (as in political analysis), and the principles of moral behaviour (as in morality). The fourth "parrhesiastic" attitude asks what political conditions are necessary and what ethos is needed to be led to the truth. Regarding power, it asks what its relation to truth is (or what connaissance there can be) and what ethos is needed to be led to power (or what ethos results from power). Regarding ethics, it asks how true discourse forms or constitutes a moral subject, and how relations of power constitute a moral subject. In sum, the parrhesiastic attitude considers that truth, power, and ethics cannot be thought independently from each other.

To these four attitudes there correspond four modes of truth and four modes of veridiction, which Foucault explains in The Courage of Truth. The prophet speaks about fate and in the name of somebody else; the modality of its truth-telling is "enigmatic". The sage or wise person speaks about being and nature (phusis); the modality of its truth-telling is apodictic. The technician, like the teacher, speaks about a techne; the modality of its truth-telling is demonstrative. In contrast to all these modes of truth, the parrhesiast "does not speak about destiny, being or techne". ${ }^{40}$ Different from the prophet, parrhesiasts do not speak about the future and in the name of somebody else, but take the risk of alienating others and speak about themselves. Different from the wise person, they do not speak about the common essence of things or the universal nature of phenomena but about "the singular form of individuals and situations". ${ }^{41}$ Different from the teacher who, as a technician, reinforces a tradition by passing on knowledge in the form of a techne, parrhesiasts speak about the subject's specific relation to the truth within particular circumstances. As such, parrhesiasts put into motion the true discourse of ethos and thus manifests in their discourse the specific balance between aletheia, politeia, and ethos. The modality of its truth-telling is polemic, Foucault tells us. It is the specific combination of these three modalities that gives a phenomenon its meaning, but a meaning that is singular and specific, as a historical event that occurs once and of course may recur, but is in its very structure of meaning "variable", so that it becomes the "event in thought" (un événement dans la pensée)..$^{42}$

I would like to show how the parrhesiastic attitude changes the way we approach truth. The fact that any approach to a phenomenon combines the three components of truth, power, and morality, first, indicates that truth is not a mere cognitive qualification of a statement, but an event in the sense that someone produces a statement in a public sphere. Let us examine each of these three components in their relation to the event.

In the summary of the lecture course The Courage of Truth Foucault associates each of the components of aletheia, politeia, and ethos with three dimensions of human beings - knowledge, power, and subject (Savoir, Pouvoir, Sujet $)^{43}$ - and the corresponding three "disciplines": (a) truth as a mode of veridiction concerns the discourse of knowledge; (b) power concerns the problems of governing others, but also, we may surmise, oneself; and (c) ethos concerns the "ethical elaboration of a subject" ${ }^{44}$

The truth in question is not about the validity of statements, but about the production of statements as true. On this point, Foucault is close to Ricoeur. Regarding the component of politeia, politics, or power, it is crucial not to confuse it with domination. Power is not negative, but a necessary components of anything human beings do. When people speak and act, they exercise and are submitted to different forms of power regarding their status, the institutions to which they belong, the political structures in which they evolve, etc. Ethics, in turn, is not a morality that has been scripted according to some principles, but rather the social and normative dimension in which people interact, what Foucault calls "modes of subjectivation" or of being a subject. 
The parrhesiastic attitude tries to be mindful of this balance of truth, power, and ethics, and thus accepts the event-character of what is said or done. This event character means that, for the parrhesiastic attitude, what matters is the non-repeatability of a phenomenon. Such an attitude is thus a thinking of the event or, as Foucault says, the thinking in the event of thought. This event character is precisely the interrelationship and interaction between the three components of aletheia, politeia, and ethos, and includes three interrelated aspects, which Foucault does not explicitly mention and to which there correspond modes of manifestation: to truth there corresponds an alethurgy, to power there corresponds a pragmatics, and to ethics there corresponds a dramatic.

Alethurgy means the "production of truth" or "the act through which the truth manifests itself" ${ }^{45}$ Truth is not merely a value of statement, but a ritual of producing truth or a "solemn ritual of truth-telling" 46 that binds the speaker to his statement or utterance. Foucault sees the "alethurgic forms" as an alternative to the "epistemological structures", which are more familiar to how we understand the truth. ${ }^{47}$ We recall that Ricoeur too speaks of an "alethic mode" about attestation. The import of parrhesia as a form of alethurgy is thus not to be sought in the internal structure of speech nor in its finality, ${ }^{48}$ but rather in

the effect that the truth-telling can produce on the addressee and the return effect that the truth-telling can produce on the speaker from the effect produced on the addressee. ${ }^{49}$

The speaker is capable of truth, and this means that the speaker is susceptible to being transformed by the truth. "Veridicity" expresses both the fact that the statement has been made true - verum dicere as "said to be true" - and that the subject has been transformed by speaking the truth - verum dicere as a true act of speech. By making a true statement the speaker manifests that he asserts it and, thus, "thinks it, values it and considers it himself as being authentically true".$^{50}$ In Ricoeurian terms, Foucault writes:

This solemn ritual of truth-telling in which the subject engages what he thinks in what he says, where he attests to the truth of what he thinks in the utterance of what he says is what is manifested in this scene, this kind of jousting [joute], this challenge. ${ }^{51}$

Foucault calls this double truth or this re-doubling of the truth a contract (pacte) between the speaker and his utterance. This contract says: first, here is the truth and, second, here I am as the one saying it. ${ }^{52}$ We recall that Ricoeur uses the same term of pacte between the historian and the readers.

Regarding politeia or the dimension of power, Foucault himself speaks of a "pragmatics" of his own thinking. While being about a long gone era of obsolete practices - like the Hellenistic period - his works are not merely an intellectual enterprise targeting a specific period in the past. They also include a performance to the extent that they are philosophical exercises aiming at freeing the very process of thinking from any guardrail, framework of reference, fashion or tradition. As stated in L'usage des plaisirs, this pragmatics consists in knowing

to learn to what extent the effort to think one's own history can free thought from what it silently thinks, and so enable it to think differently. ${ }^{53}$

With regard to ethos the parrhesiastic attitude includes a "dramatic of discourse". ${ }^{44}$ Just as the truth is not a mere neutral qualification of a statement or a proposition as its validity, but a ritual of alethurgy: it is a production of the truth; and just as power is not an added feature of an act or activity of thinking, but a pragmatics of thinking: thinking is a practice with its own discipline and its own techniques. Similarly, ethics is not a separate activity or reflection bearing upon external objects like an action, but an intrinsic component of any action, the action of thinking included. This ethos of thinking turns discourse into a drama through which someone becomes a subject. The "dramatic of discourse" Foucault speaks of consists in this, that speakers 
cannot be considered merely as those who want to say something or intend or mean something. Rather, speakers, as participating in an alethurgy (as production of truth) and in a pragmatics (as a performer on the stage of thinking), are also protagonists in the event of speech and they will be transformed by what is said. The drama is unfolding in time and thus linked to the kairos ${ }^{55}$ in such a way that speakers are not only bound to their own utterance but also to the consequences of what they said. ${ }^{56}$ Speaking up transforms speakers not just because they spoke the truth, but because the utterance transforms the situation of that utterance, opening up ${ }^{57}$ "a certain number of effects that are precisely not known". Parrhesia "opens an undetermined risk". ${ }^{58}$ The drama requires courage from the speaker as a protagonist. Because of the risk and the required courage on the part of speakers, "parrhesia is the ethics of telling the truth, in one's risky and free act". ${ }^{59}$

These three parameters of truth (corresponding to an alethurgy), power (corresponding to a pragmatics), and ethics (corresponding to the drama of discourse as a mode of subjectivation) situate the event of thought, which consists in an interaction between subject and truth. As Foucault says about philosophy as a parrhesiastic attitude, these three components make it clear that the logos of the discourse, which consists in telling the truth, has to be accompanied by an ergon as the action of the one who speaks the truth. Foucault sees this in Plato himself as the adviser to the politician Dionysius of Sicily. ${ }^{60}$

Now that we have reviewed Ricoeur's attitude of truth-telling and Foucault's parrhesia (as alethurgy, pragmatics, and drama of discourse), we can assess the extent to which attestation and parrhesiastic attitude of the investigator share a strong commonality in that they are both existential attitudes, yet also how they differ. They differ, first, in their scope and, second, in the justification they recognize for themselves.

Regarding scope, attestation continues the ideal of hermeneutics of bridging differences and assuring continuity between the temporality of the investigator - the present - and the temporality of the object investigated present or past. In this regard, attestation builds a tradition and offers itself as the cement of such a tradition. Although Ricoeur also acknowledges that the event is beyond representation as what incites and motivates representations, the event remains the "ultimate referent" and, as such, the limit of historical representations as what can always correct them. While it is through an existential and ethical attitude that the reference of the narrative is guaranteed, there is reference. Ricoeur's poetics of truth is thus political only in the limited sense that historians "produce" truth. However, the role of counterpart that the event plays allows historians to claim universality in the form of an ideal correspondence to fact. The claim to universality is even inscribed in the "assertive vehemence" 61 of their accounts that "refer" to the events as they "really" happened. Attestation may be an existential and ethical attitude, but it is at the service of the reference made to the event that "actually" happened. It is a standing up for what one says and presenting oneself as a guarantee of reference. As a consequence, attestation may well be a poetics of truth in the sense that, in the case of history, historians through narratives "invent" history in the qualified sense we mentioned: a configuration that offers to the event, which cannot give itself, a chance to address us and make us respond. However, precisely because attestation is existential and ethical, it transcends the politics of writing history and remains committed to the existence of a referent, however ultimate this may be.

By contrast, the parrhesiastic attitude tries to avoid continuity and avoids using the present as its starting point in order to build a tradition. This would turn the investigation of the past as a retrospective consideration that sees the past object as leading to the present of the investigator. Parresiasts, such as Foucault, try to free themselves from their present and look at the past otherwise than as what prepared their perspective. Instead of building a tradition, as attestation, the parrhesiastic attitude disrupts the tradition and tries to find a perspective on our present that does not originate from such a present despite the fact that the parrhesiasts live in it. Remarkably, this looks like an epoche that allows the gaze to escape its own historical inscription in a tradition. Against the phenomenological reduction, though, the goal is not to bring what is "reduced" to some form of evidence. On the contrary, the goal of the parrhesiastic attitude is to provoke discussion by countering 
accepted views and proposing an alternate view. As Foucault indicates in Le courage de la vérité, the modality of truth-telling proper to the parrhesiastic attitude is "polemic", instead of "hermeneutic", as in Ricoeur. It is polemic because the meaning to be given to a phenomenon through parrhesiastic statements in a dramatic of discourse will locate this phenomenon in its unique historical place and such a meaning, of necessity, will be, as Foucault says, "variable" and "never universal". While the fact that meaning is variable also means that it is a variation on our present, which, as such, gives us alternatives and new possibilities - it in fact and essentially liberates our present. These two aspects of meaning as never universal and of the investigation to liberate our present go against Ricoeur's whole hermeneutic enterprise of bridging the gaps in the continuity of a tradition.

This leads to the second fundamental difference between attestation and the parrhesiastic attitude: the kind of justification they recognize for themselves. While both reject a formalism of rules whether of propositional truth, argumentation, or pragmatics, and strongly defend the existential nature of truth as a process that involves those who "speak the truth", the existential justification they defend is rather different. Attestation is an attitude that addresses past, present or future discussants and recognize these discussants as those to whom an obligation is due or a right is recognized. Attestation is essentially dialogical and in this dialogue investigators present themselves as participants in a justification process in which they say: "Here I am, standing by what I said and here are the evidence upon which my account is based. Examine the evidence and show me where I erred and I will recognize it". This dialogical nature of the attitude of attestation guarantees that the present of investigators and their critics is, on the one hand, a shared present and, on the other - and it was the first difference with the parrhesiastc attitude - a present that is in continuity with the past, as shaping a tradition.

By contrast, parrhesiasts do not so much attest as they dare offer their views in the dual meaning of having the audacity to do so and challenging us in our received views. It is not attestation because the parrhesiastic attitude does not include an obligation of justifying oneself towards other people. The justification is rather towards oneself and to the circumstances and the event. It is not about reliability towards others, but courage towards the circumstances. This is why it is a history of the present: it is as if the present were told from the perspective of the past so that the present is seen itself as an event, in its flux and contingency, in its uncertainty and arbitrariness, all features that attestation attempts to eliminate.

When the writing of history is a drama of discourse, as in Foucault, the truth, even if ethical, will remain political and, as such, singular and polemic. Now, Foucault could respond that parrhesia, which is also ethical, is of necessity intrinsically political, just like Ricoeur's attestation, because both arise out of the present so that the past is presentable not as what "actually happened", in a referential gesture, but as a comparable. ${ }^{62}$ Foucault could point to two assumptions in Ricoeur's referential gesture, which the parrhesiastic attitude rejects. The first assumption consists in taking the past as the point of reference, towards which the present historian attests through a narrative. Against such an assumption, since the past as gone - or the event - is not directly presentable, it is always with regard to our present and over against our present that we can see in past practices or past events something that stands out as differing from our representations or resisting them. The investigations of the past are in fact part of a history of the present.

The second assumption in Ricoeur's attestation that the parrhesiastic attitude rejects consists in relying on a continuity between the past and the present so that we can transpose ourselves back into the past like explorers who see in foreign cultures mere variations of their own customs and habits. Against such an assumption, the parrhesiastic attitude is an intellectual discipline of suspending - in the phenomenological sense, despite Foucault's suspicion towards phenomenology - the factual historical continuity that exists between our present and the past. Although we take our present as a point of reference, we do not use it as a perspective or as a measuring rod. The reason for this suspension of intellectual continuity is that the factual historical continuity tends to lead us to look back at the past in a retrospective illusion: as if we are at the end of an evolution or the result of a progress coming from the past, making us see the past as what leads to us as its telos, preparing us as 
its achievement. By rejecting this second assumption, the parrhesiastic attitude commits itself to singularity so that the event of what is investigated can become apparent to us in its own radicality - in its roots once we have severed the factual historical continuity it had with our present and which prevented its past to be its own instead of ours. We do not have an irenic attitude of arbitrating among competing views, as attestation presents itself to be, but an attitude that embraces polemic not out of iconoclastic pleasure, but as a mental discipline so as to be able to challenge the most entrenched philosophical and social views. The parrhesiastic attitude is unwittingly, although lucidly, positively polemic.

\section{Acknowledgement}

I would like to thank Marisola Xhelili and Peter Burgess for their editorial help. I am also grateful for the comments and fruitful suggestions made by the two anonymous reviewers of the journal.

\section{Notes}

1 Both Foucault and Ricoeur have provided detailed accounts of what they see as the shortcomings of the speech act theory and the pragmatics of discourse. Foucault addresses these questions in Archaeology of Knowledge, in which he appeals to a notion of "statement" that is neither the sentence nor the proposition, but the historically situated event of utterance. Ricoeur deals with this issue in his many examinations of action (in From Text to Action), of time (Time and Narrative), selfhood (Oneself as Another), and the past (Memory, History, Forgetting).

2 La mémoire, I'histoire, I'oubli. Paris: Editions du Seuil, Collection Points, 2000, 363; Memory, History, Forgetting, trans. Kathleen Blamey and David Pellauer. Chicago: The University Press of Chicago, 2004, 278.

3 La mémoire, I'histoire, l'oubli, 366; Memory, History, Forgetting, 279.

4 Temps et récit 3 Le temps raconté. Paris: Les Editions du Seuil, Collection Points, 1985, 285; Time and Narrative vol 3, trans. Kathleen Blamey and David Pellauer. Chicago: University of Chicago Press, 1988, 157. Translation modified.

5 Temps et récit 3, 279. Ricoeur's emphasis; Time and Narrative vol 3, 154. Translation modified.

6 Temps et récit 3, 280; Time and Narrative vol 3, 155.

7 La mémoire, I'histoire, l'oubli, 369; Memory, History, Forgetting, 567.

8 Soi-même comme un autre. Paris, Editions du Seuil, Collection Points, 1990, 335; Oneself as Another, trans. Kathleen Blamey. Chicago: The University of Chicago Press, 1992, 289.

9 Paul Ricoeur, "L'attestation: entre phénoménologie et ontologie", in Paul Ricoeur. Les avatars de la raison herméeneutique, ed. Jean Greisch et Richard Kearney. Paris: Editions du Cerf, 1991, 381-403.

10 "Le témoin croit à ce qu'il dit et on croit en la sincérité du témoin" (“L'attestation”, 382).

11 "L'attestation est la sorte de confiance ou d'assurance (statut épistémologique non doxique) que chacun a d'exister (statut ontologique) sur le mode du soi (statut phénoménologique)" ("L'attestation", 382).

12 La mémoire, I'histoire, l'oubli, 162; Memory, History, Forgetting, 132.

13 Temps et récit 3, 446; Time and Narrative vol 3, 248. Translation modified.

14 Temps et récit 3, 284; Time and Narrative vol 3, 157.

15 La mémoire, I'histoire, I'oubli, 367; Memory, History, Forgetting, 280.

16 La mémoire, I'histoire, l'oubli, 227; Memory, History, Forgetting, 178-9.

17 La mémoire, I'histoire, l'oubli, 227; Memory, History, Forgetting, 179.

18 La mémoire, I'histoire, I'oubli, 228; Memory, History, Forgetting, 179.

19 La mémoire, I'histoire, l'oubli, 228; Memory, History, Forgetting, 179. Translation modified.

20 La mémoire, I'histoire, l'oubli, 339; Memory, History, Forgetting, 261.

21 La mémoire, I'histoire, l'oubli, 339; Memory, History, Forgetting, 261.

22 La mémoire, l'histoire, l'oubli, 359; Memory, History, Forgetting, 275.

23 La mémoire, I'histoire, l'oubli, 363-4; Memory, History, Forgetting, 278.

24 Temps et récit 3, 253; Time and Narrative vol 3, 143. 
25 Carr, David, Charles Taylor, Paul Ricoeur. "Discussion: Ricoeur on Narrative". In On Paul Ricoeur. Narrative and Interpretation, ed. David Wood. London: Routledge, 1991, 187.

26 Temps et récit vol. 3, 272; Time and Narrative vol 3,152.

27 La mémoire, I'histoire, I'oubli, 473; Memory, History, Forgetting, 363. Translation modified.

28 Temps et récit 1, Paris, Editions du Seuil, Collection Points, 1983, 143; Time and Narrative, vol. 1. Chicago: University of Chicago Press, 1984, 75.

29 See Eduard Klain quoted in Trudy Govier, Forgiveness and Revenge. London: Routledge, 2002, 34.

30 Temps et récit vol. 1, 143; Time and Narrative, 1, 75.

31 Temps et récit vol. 1, 366; Time and Narrative, 1, 208-9.

32 Temps et récit 3, 364; Time and Narrative vol. 3, 202.

33 La mémoire, I'histoire, l'oubli, 363; Memory, History, Forgetting, 278.

34 "The phenomenology of testimony led the analysis of attestation to the threshold of doing history" (La mémoire, l'histoire, l'oubli, 510; Memory, History, Forgetting, 392.

35 Foucault reflected upon it in his last three lecture courses at the Collège de France from 1981 to 1984, the year of his death, The hermeneutics of the Subject, The Government of Oneself and Others, and The Courage of Truth, respectively, as well as in a seminar on "Discourse and Truth" at Berkeley in 1983, published under the title Fearless Speech, ed. Joseph Pearson. Los Angeles: Semiotext(e), 2001.

36 For the French translation Foucault uses the word franc-parler (Le gouvernement de soi et des autres, 46; The Government of Self and Others, 46).

37 This is also the view of Thomas Flynn who has a chapter titled "Foucault as Parrhesiast" in his book Sartre, Foucault, and Historical Reason, Vol. 2 A Poststructuralist Mapping of History. Chicago: The University of Chicago Press, 2005, 260f.

38 L'herméneutique du sujet, 444; Hermeneutics of the Subject, 462.

39 Le courage de la vérité. Le gouvernement de soi et des autres II. Cours au Collège de France. 1983-1984. Ed. Frédéric Gros. Paris: Gallimard/Seuil, 2009, 63-65; The Courage of Truth (The Government of Self and Others II); Lectures at the Collège de France, 1983-1984, ed. Frédéric Gros, trans. Graham Burchell. New York: Palgrave Macmillan, 2011, 66-69.

40 Le courage de la vérité, 25; The Courage of Truth, 25.

41 Le courage de la vérité, 25; The Courage of Truth, 25.

42 L'herméneutique du sujet, 11; Hermeneutics of the Subject, 9.

43 Le courage de la vérité, 317; The Courage of Truth, 346.

44 Le courage de la vérité, 317; The Courage of Truth, 346.

45 Le courage de la vérité, 5 ; The Courage of Truth, 3.

46 Le gouvernement de soi et des autres, 62; The Government of Self and Others, 64.

47 Le courage de la vérité, 5; The Courage of Truth, 3.

48 Le gouvernement de soi et des autres, 56; The Government of Self and Others, 56.

49 Le gouvernement de soi et des autres, 56; The Government of Self and Others, 56.

50 Le gouvernement de soi et des autres, 62; The Government of Self and Others, 64.

51 Le gouvernement de soi et des autres, 62; The Government of Self and Others, 64.

52 Le gouvernement de soi et des autres, 62; The Government of Self and Others, 65.

53 Michel Foucault, Histoire de la sexualité 2. L'usage des plaisirs. Paris: Gallimard, 1984, 15; The History of

Sexuality, Vol. 2 The Use of the Pleasure, trans. Robert Hurley. New York: Vintage books, 9.

54 Le gouvernement de soi et des autres, 66; The Government of Self and Others, 68.

55 L'herméneutique du sujet, 367; Hermeneutics of the Subject, 384.

56 Le gouvernement de soi et des autres, 56; The Government of Self and Others, 56.

57 Le gouvernement de soi et des autres, 63; The Government of Self and Others, 66.

58 Le gouvernement de soi et des autres, 60; The Government of Self and Others, 62.

59 Le gouvernement de soi et des autres, 64; The Government of Self and Others, 66.

60 Le gouvernement de soi et des autres, 202; The Government of Self and Others, 218.

61 La mémoire, I'histoire, l'oubli, 367; Memory, History, Forgetting, 280. 
62 Ricoeur himself uses this term in his book Sur la traduction, Paris: Bayard, 2004, which he borrows from Marcel Detienne (Comparing the Incomparable, trans. Janet Lloyd. Stanford, CA: Stanford University Press, 2008).

\section{Bibliography}

1. Carr, David, Charles Taylor, and Paul Ricoeur, "Discussion: Ricoeur on Narrative", in On Paul Ricoeur: Narrative and Interpretation. London: Routledge, 1991.

2. Detienne, Marcel, Comparing the Incomparable, trans. Janet Lloyd. Stanford, CA: Stanford University Press, 2008.

3. Flynn, Thomas, "Foucault as Parrhesiast", in Sartre, Foucault, and Historical Reason, Vol. 2, A Poststructuralist Mapping of History. Chicago: The University of Chicago Press, 2005, $260 f$.

4. Foucault, Michel. L'archéologie du savoir. Paris: Gallimard, 1969. English translation: The Archaeology of Knowledge and The Discourse on Language, trans. A.M. Sheridan Smith. New York: Vintage Books, 2010.

5. Foucault, Michel, Le courage de la vérité. Le gouvernement de soi et des autres II. Cours au Collège de France. 1983-1984, ed. Frédéric Gros, François Ewald, and Alessandro Fontana. Paris: Gallimard/Seuil, 2009. English translation: The Courage of Truth (The Government of Self and Others II); Lectures at the Collège de France, 1983-1984, ed. Frédéric Gros, François Ewald, and Alessandro Fontana, trans. Graham Burchell. New York: Palgrave Macmillan, 2011.

6. Foucault, Michel, Fearless Speech, ed. Joseph Pearson. Los Angeles: Semiotext(e), 2001.

7. Foucault, Michel, Le gouvernement de soi et des autres. Cours au Collège de France. 1982-1983, ed. Frédéric Gros, François Ewald, and Alessandro Fontana. Paris: Gallimard/Seuil, 2008. English translation: The Government of Self and Others; Lectures at the Collège de France, 1982-1983, ed. Frédéric Gros, François Ewald, and Alessandro Fontana, trans. Graham Burchell. New York: Palgrave Macmillan, 2010.

8. Foucault, Michel. L'herméneutique du sujet: Cours au Collège de France, 1981-1982, ed. Frédéric Gros, François Ewald, Alessandro Fontana. Paris: Gallimard/Seuil, 2001. English translation: The Hermeneutics of the Subject: Lectures at the Collège de France, 1981-1982, ed. Frédéric Gros, François Ewald, and Alessandro Fontana, trans. Graham Burchell. New York: Picador, 2005.

9. Foucault, Michel, Histoire de la sexualité 2. L'usage des plaisirs. Paris: Gallimard, 1984. English translation: The History of Sexuality, Vol. 2 The Use of the Pleasure, trans. Robert Hurley. New York: Vintage books.

10. Govier, Trudy, Forgiveness and Revenge. London: Routledge, 2002.

11. Ricœur, Paul, "L'attestation: entre phénoménologie et ontologie", in Paul Ricoeur. Les avatars de la raison herméneutique, ed. Jean Greisch and Richard Kearney. Paris: Editions du Cerf, 1991, 381-403.

12. Ricœur, Paul, La mémoire, I'histoire, l'oubli. Paris: Editions du Seuil, Collection Points, 2000. English translation: Memory, History, Forgetting, trans. Kathleen Blamey and David Pellauer. Chicago: The University Press of Chicago, 2004.

13. Ricœur, Paul, Soi-même comme un autre. Paris, Editions du Seuil, Collection Points, 1990. English translation: Oneself as Another, trans. Kathleen Blamey. Chicago: The University of Chicago Press, 1992.

14. Ricœur, Paul. Sur la traduction. Paris: Bayard, 2004.

15. Ricœur, Paul, Temps et récit 3 Le temps raconté. Paris: Les Editions du Seuil, Collection Points, 1985. English translation: Time and Narrative vol 3, trans. Kathleen Blamey \& David Pellauer. Chicago: University of Chicago Press, 1988.

16. Ricœur, Paul, Du texte à l'action. Essais d'herméneutique II. Paris: Les Editions du Seuil, 1986. English translation: From Text to Action. Essays in Hermeneutics, II. Evanston, IL: Northwestern University Press, 1991. 